\title{
PROBLEMS AND PROSPECTS OF IMPLEMENTATION THE STRUCTURES OF THE INTELLECTUAL ELECTRICITY NETWORKS IN UKRAINE TO INCREASE THE LEVEL OF ENERGY SECURITY
}

Formulation of the problem. Functioning of energy enterprises of Ukraine, energy sphere as a whole in the conditions of market economy occurs at a high level of uncertainty and unpredictability.

The prolonged, deep political, economic, and energy crisis in the country has caused many unforeseen dangers and threats to the energy sector of the economy. Its development is also influenced by such factors as the unstable political and social situation in the country, imperfect energy legislation, the criminalization of society, government and business, corruption, fraud and others. All this aggravates the problem of ensuring a high level of energy security [1, p. 223-224]. These factors (factors) encourage the development of methods for improving the efficiency of economic entities in the field of energy, ensuring their stable functioning and harmonious development. One of these directions is the introduction of structures of smart electricity networks.

Analysis of recent research and publications. In recent years, interest in "smart grids" in the energy sector has increased significantly, in particular the number of scientific publications devoted to this. This testifies to their relevance and development. Technological support, prospects of their introduction and development in the energy sector of Ukraine were studied by the following specialists: S. Denysyuk [2], S. Dudnikov [3], S. Dubko [4], O. Kirilenko [2], O. Moroz [4], Popadchenko S.A. [4], Prahovnik A.V. [2, 5], O. Savchenko [4], B. Stogny [1], S. Tulchinskaya [6], M. Cheremisin [4], M. Chernyshov [6] and others.

Also important and equally important are the issues of energy security, which are being actively researched by domestic scientists, such as: O. Dzoba [7, 8], S. Kafka [8], K. Kulakovsky [9], O. Latysheva [10], L. Logachova [11], M. Muzichenko [12], O. Novikova [11], A. Lieutenant [9], L. Simkov [8], R. Opimach [13], A. Stepanova [14] and others.

However, studies have shown that today they are still insufficiently enlightened, analyzed and solved, needing further in-depth study of the problem and prospects of implementing the structures of intelligent power grids in Ukraine in order to increase the level of energy security.
The purpose of the article is to investigate the problems and prospects of the processes of development, implementation of structures of intelligent electricity networks in Ukraine in order to increase the level of energy security.

Presenting main material. At any point in the functioning of an energy enterprise, the energy industry as a whole of any country, there is a potential risk of crisis, even if crisis phenomena are not observed, when they are non-existent and cannot be predicted. This is primarily because the global socio-economic system, including the energy sector, is developing cyclically. The external environment is also developing dynamically, the ratio of managed and unmanaged processes is changing, the needs for energy resources (sources) and interests of society, the needs for these resources of production and other spheres of life and so on are changing. Therefore, the main task to maintain an acceptable level of stability will be in the process of avoiding critical and, even more so, catastrophic risks in order to avoid (prevent) the emergence of a crisis in the energy sector (and as a result, the economy as a whole). Therefore, energy security is a state of the energy sector's potential, which guarantees the highest level of efficient use of energy resources, timely, sufficient level of energy resources for the stable functioning of the country's economic system, its further harmonious development, etc.

The level of energy security will depend on how effectively its government, experts in the field are able to avoid (prevent) possible threats, eliminate the harmful effects of certain negative components of the external / internal environment, etc.

One of the ways to maintain a high level of energy security is to diversify energy resources, to use combined energy supply systems with renewable (renewable) energy sources (RES), taking into account the Smart Grid concept. Significant contribution to the development and design of combined energy supply systems with renewable (renewable) energy sources (RES), taking into account the Smart Grid concept, was made by S. Dudnikov [3, p. 67-69].

According to the research, the existing (existing) power grids in Ukraine are exclusively constructed un- 
der the so-called "centralized power supply" scheme. This scheme requires the use of higher voltage, the creation of large-scale electrical networks.

In networks of this type, even small local disruptions can have a significant impact on the entire energy system of our country, even leading to large-scale crashes.

New conditions, factors, catalysts for the development of the energy sector of Ukraine in the context of European integration shape the need for the development, further active introduction of new (newest) technologies, elements, components that will allow to provide: movement of electricity flows, movement (flows) of information from energy companies to consumers and backwards; the process of continuous monitoring (with the possibility of further prompt and timely regulation (if necessary, in case of deviations from the planned indicators (parameters, indicators, etc.) for all elements of the network, from the activity of the country's power plants to the final consumption of electricity by individual devices; integration of the distributed power sources production; energy (including RES) and the means of storage of the generated electricity; heat recovery and the like.

Transformation of energy markets of the world (in particular the EU), crisis in Ukraine (in energy, economy), the latest trends in the EU energy sector, the need to ensure a sufficient level of energy (as a component of economic and national) security, other factors have led to the need for new positioning of economic policy Ukraine in the field of energy (fig. 1).

\begin{tabular}{|c|c|c|}
\hline $\begin{array}{l}\text { Increasing rates of harmonious } \\
\text { development of computer, } \\
\text { information technologies, } \\
\text { increasing the level of automation } \\
\text { of energy processes }\end{array}$ & $\begin{array}{c}\text { New standards (European, world), } \\
\text { conditions for the formation } \\
\text { of rules, behaviors of participants } \\
\text { in the energy markets (including } \\
\text { electricity) }\end{array}$ & $\begin{array}{l}\text { Balancing the interests of "pro- } \\
\text { ducer", "supplier", "consumer" of } \\
\text { energy resources, provided the } \\
\text { harmonious development of com- } \\
\text { petitive energy markets (especially } \\
\text { electricity and natural gas markets) }\end{array}$ \\
\hline $\begin{array}{l}\text { Intense growth in the number } \\
\text { of small generating (including } \\
\text { renewable) energy sources }\end{array}$ & & $\begin{array}{l}\text { Changing internal conditions of } \\
\text { functioning of energy markets }\end{array}$ \\
\hline & Requirements for the new & $\begin{array}{c}\text { Increasing level of economic } \\
\text { instability }\end{array}$ \\
\hline $\begin{array}{l}\text { Global price trends for energy } \\
\text { resources (sources) }\end{array}$ & $\begin{array}{l}\text { positioning of Ukraine's } \\
\text { energy policy }\end{array}$ & $\begin{array}{l}\text { Reforming the organization of the } \\
\text { energy sector in most countries }\end{array}$ \\
\hline $\begin{array}{c}\text { The harmonious development } \\
\text { of the market for greenhouse gas } \\
\text { emissions }\end{array}$ & & $\begin{array}{l}\text { Long-term investment and life } \\
\text { cycle of the assets and energy } \\
\text { sector as a whole }\end{array}$ \\
\hline $\begin{array}{l}\text { The increasing level of wear and } \\
\text { tear of the equipment, the need for } \\
\text { its renovation, repair, re-equip- } \\
\text { ment / replacement, the need for } \\
\text { massive investments in renovation }\end{array}$ & $\begin{array}{c}\text { Reducing the overall level } \\
\text { of security of energy supply } \\
\text { in Ukraine, reducing the level } \\
\text { of energy security }\end{array}$ & $\begin{array}{l}\text { Increasing the level of require- } \\
\text { ments for the set and quality of en- } \\
\text { ergy services, increasing the level } \\
\text { of requirements for information } \\
\text { transparency of the system of rela- } \\
\text { tions between the subjects of the } \\
\text { energy markets (consumers) }\end{array}$ \\
\hline
\end{tabular}

Fig. 1. Scheme of interaction of factors in repositioning of Ukraine's energy policy

Note: Created by the authors.

The research shows that an innovative energy system based on the Smart Grid concept has significant advantages over the current one in Ukraine. The main advantages include the following: cost-effectiveness, efficiency and controllability of the system. The development and implementation of functionality (table 1) will significantly increase the level of power efficiency, and provide the expected benefits for all stakeholders. 
Realization of key requirements on the basis of basic approaches can be ensured by the development of traditional in combination with creation of new functional properties of the grid of Ukraine, its key elements.
In the table 1 gives a comparative description of the functional properties of the current (active) energy system of Ukraine and the potential energy system that is created on the basis of the implementation of the Smart Grid concept.

\section{Comparative characterization of the functional properties of the Energy system of Ukraine and the Energy system based on the Smart Grid concept}

\begin{tabular}{|c|c|}
\hline The current energy system of Ukraine & $\begin{array}{c}\text { Innovative energy system based } \\
\text { on Smart Grid concept }\end{array}$ \\
\hline One-way communication between elements or lack thereof & Two-way communication \\
\hline $\begin{array}{l}\text { Centralized Generation - Distributed generation with a } \\
\text { complex integration process }\end{array}$ & Distributed generation \\
\hline Radial topology prevails & Network topology prevails \\
\hline Responding to the consequences of an accident & $\begin{array}{l}\text { Responding to predicting and preventing (preventing) } \\
\text { an accident }\end{array}$ \\
\hline $\begin{array}{l}\text { Operation of the equipment until complete failure (break- } \\
\text { down) }\end{array}$ & $\begin{array}{l}\text { Continuous monitoring, self-diagnosis, which help to } \\
\text { extend the life of the equipment }\end{array}$ \\
\hline Manual recovery for errors, crashes, etc. & $\begin{array}{l}\text { Automatic Network Recovery (Self-healing Net- } \\
\text { works) }\end{array}$ \\
\hline High level of system crashes & $\begin{array}{l}\text { Forecasting the development of system crashes, pre- } \\
\text { dicting their occurrence }\end{array}$ \\
\hline Manual, fixed network allocation & Adaptive network allocation \\
\hline Checking the equipment on site & Remote monitoring of equipment \\
\hline Limited power flow control & General power flow control \\
\hline End-user pricing information is not available or too late & Consumer price level is displayed in real time \\
\hline
\end{tabular}

Note: authors based on [15].

The beginning for the development of the concept of "Smart Grid" in industrialized countries was the formation of a clear strategic vision of goals, objectives of electricity development, which would meet the evergrowing demands of society, stakeholders, namely: states, science, manufacturers, economy, entrepreneurship, consumers, etc. (fig. 2).

Therefore, the structure of smart electricity grids in Ukraine is promising for use.

To connect renewable energy sources to the grid of the country under the conditions of the electricity market development, it is necessary to use the appropriate Smart Grid systems for the purpose of automated management of energy flows, timely regime regulation of flows, electricity consumption by system maneuverability and so on. This is also related to the level of development of the country's electric transport (it has been happening rapidly in Ukraine in recent years, starting in 2016) [16].

The main trends in the development of Smart Grid systems are the automated management of large amounts of information; introduction of modern (in particular intelligent transformers); integration of all systems of accumulation (storage) of electric energy in commercial electric grids; software development, Internet networking, etc.; development of "Internet services", subscription systems for electricity; development of intelligent sensors (primarily thermostats), other intelligent systems, etc.
Major European Smart Grid projects include the following: ECOGRID (an initiative-driven multi-technology project to manage consumption with 28,000 residents, 300 large consumers and $56 \mathrm{MW}$ of renewable energy generation, costing $€ 21$ million, completed in 2014); DDRESS (managed distribution network for "active consumer" integration, demonstration, multi-technology project involving 400 consumers. Cost - EUR 16 million, completed in 2012; GRID4EU (research, demonstration, multi-technology project worth EUR 54 million) will be completed in 2018; GREEN eMOTION (a comprehensive project consisting of nine multi-technology projects for the study of the integration of power stations to charge electric vehicles, optimal charging circuits, etc.) worth EUR 24.2 million, completed in 2015, etc. [15].

In our opinion, the most complete, general functional and technological ideology of the concept of "Smart Grid" was reflected by the Institute of Electrical and Electronics Engineers. According to him, "Smart Grid" is the concept of a fully integrated, self-regulating, self-sufficient, self-renewing electricity system, which has a network topology, includes all generating sources, backbone, distribution networks, all types of electricity consumers, managed by a single network in real time [15].

"Smart Grid" systems are required for the process of connecting renewable energy sources to the large grid under conditions of constant development of the 


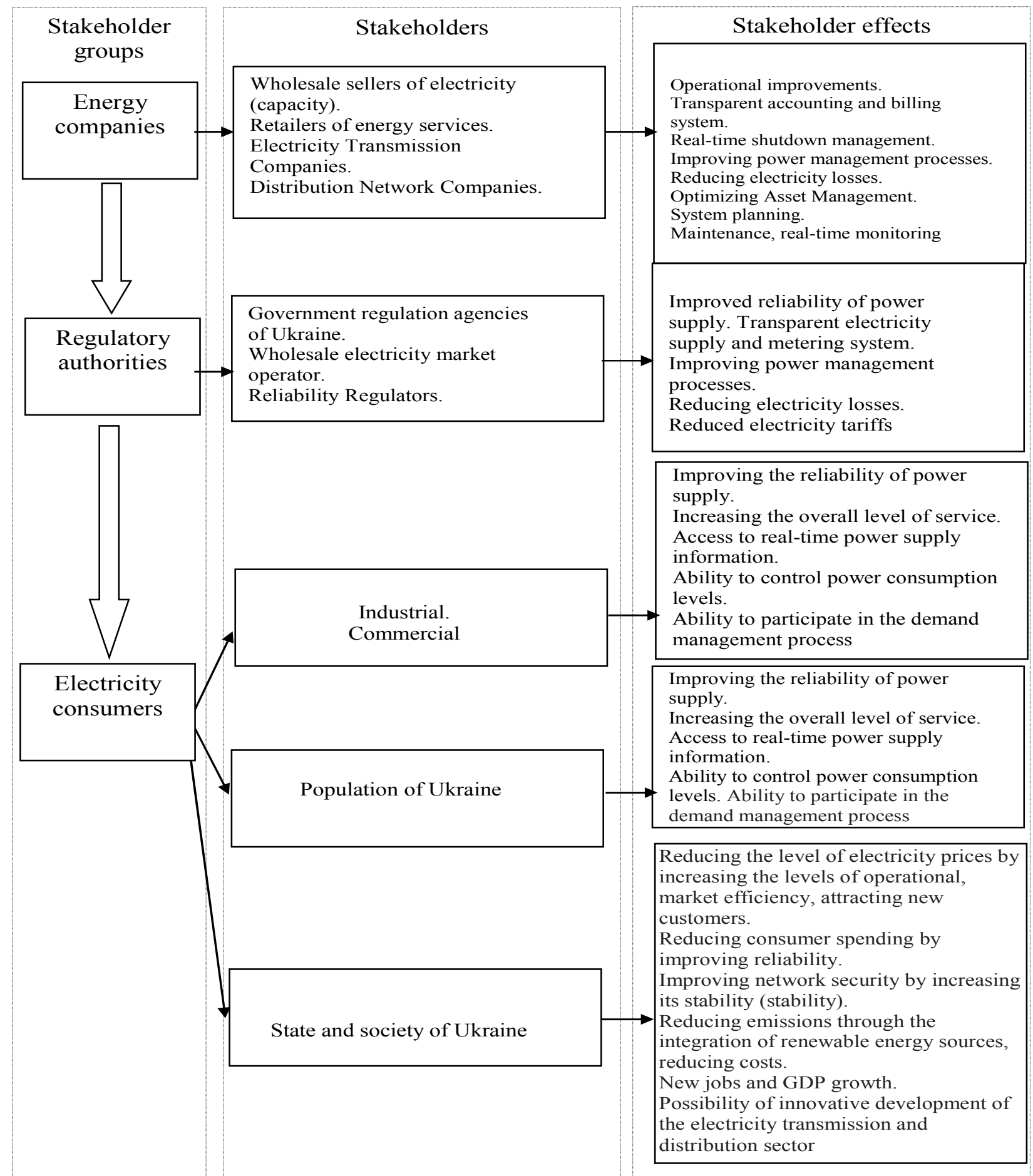

Fig. 2. The system of interconnection of the stakeholders, requirements and effects in the process of implementation of the Smart Grid concept in the energy sector of Ukraine

Note: systematized based on [15].

Ukrainian electricity market. Their need is the automatic control of energy flows, timely regulation of leakage, power consumption by system maneuverability.

Therefore, the movement towards the implementation of Smart Grid systems in Ukraine is closely linked to the objective and rigid need to increase the level of economic efficiency of electricity in the context of increasing energy consumption, limited energy resources.
Implementation of the Smart Grid model in Ukrainian energy will not only optimize existing algorithms for generating, transferring energy, expanding potential uses of alternative sources, but will also make significant adjustments to the energy development strategy, energy policy of the country, change their approach to structure development, management systems. activities of energy companies. 
Ukraine should actively join the global community in the process of building a green economy and energy, which in the future will not only solve energy and environmental problems, but also help create the conditions for solving social problems, improve the quality and efficiency of public administration, create conditions for long-term economic growth.

As the research showed, the following are the main problems $[17,18,19]$ :

- the need to accumulate a significant amount of financial resources globally;

- technological obstacles;

- information asymmetry.

The latter problem is decisive, hindering the harmonious development of the necessary technologies, preventing energy market participants from adequately assessing the existing risks and opportunities of energy projects related to green energy construction.

The low speed of information exchange hindered the achievement of the goals of harmonious development (transformation of the world energy system into "green", combination of interests of all participants of relations in the energy market). It is the blockchain system that can solve this problem. In contrast to its use in the financial sector of the world economy (the ability to accelerate financial transactions), in the energy sector, this system allows direct interaction of suppliers with buyers of energy resources (excluding intermediaries intermediaries who in Ukraine monopolized the electricity and natural gas market).

The blockchain system in the energy sector will also help to create the conditions for the accumulation, processing, analysis of vast arrays of non-financial information. This information is contained in the agreements and is unified, which makes it important for both energy market participants and representatives of the financial sector of the economy. This applies to the physical characteristics of energy resources: fuel, electricity, etc.

Conclusions and prospects for further research. In summary, it should be noted that the state of development, implementation of "smart" systems "Smart Grid", "Smart Metering", blockchain technology in the Ukrainian electricity industry has absolutely no systematic, and is carried out only in separate areas. This is due to the absence in Ukraine of a single integrated concept of building "smart" grids (neither in the United Energy System of Ukraine nor in other branches of the country's economy). First of all, it concerns the most energyintensive industries.

The following conclusions, as a result of the study, can be drawn: the priority direction to ensure a high level of energy, economic and national security of Ukraine should be to achieve the appropriate level of stability of energy sector entities, minimize the impact of human factors, such as distraction and implementation, and effective use of structures of intelligent electricity networks. Ukraine should lead by example and follow the experience of the European Union, USA,
China, other countries where at the state level are adopted, national concepts of development, financing of "smart" grids in electricity, other branches of economy, which became the basis for shaping national energy policies, are successfully implemented, programs, energy development strategies and more.

\section{Literature}

1. Троц I.B. Забезпечення економічної безпеки на підприємстві з метою попередження банкрутства. Bicник ЖДТУ. 2012. № 1. С. 223-227. 2. Стогній Б.С., Кириленко О.В., Праховник А.В., Денисюк С.П. Еволюція інтелектуальних електричних мереж та їхні перспективи в Україні. Технічна електродинаміка. 2012. № 5. С. 52-67. 3. Дудніков С. М. Деякі аспекти проектування комбінованих системи енергопостачання з поновлювальними джерелами 3 врахуванням концепції Smart Grid. Комунальне господарство міст. 2014. Вип. 118 (1). С. 67-70. 4. Мороз О.М., Черемісін М.М., Савченко О.А., Попадченко С.А., Дюбко С.В. Використання технологій Smart Grid для підвищення ефективності електропостачання споживачів. Енергетика: економіка, технології, екологія. 2017. № 3. 5. Праховник А.В. Від управління електроспоживанням до енергетики сталого розвитку. Вісник НТTУ КПI». Серія «Гірництво». 2010. Вип. 19. С. 110-121. 6. Чернишова М.I., Тульчинська С.О. Впровадження проекту "розумні мережі" в контексті розвитку паливно-енергетичного комплексу України. Ефективна економіка. 2016. № 11. URL: http://www.economy.nayka.com.ua/ ?op=1\& $\mathrm{z}=5272$. 7. Дзьоба О.Г. Про деякі аспекти оцінювання енергетичної безпеки з урахуванням ризиків суб'єктів паливно-енергетичного комплексу. Науковий вісник Івано-Франківського національного технічного університету нафти і газу. Серія «Економіка та управління в нафтовій $і$ газовій промисловості». 2016. № 1 (13). С. 37-41. 8. Дзьоба О.Г., Сімків Л.Є., Кафка С.М. Економіко-управлінські аспекти трансформаџії та інноваційного розвитку соиіально-економічних систем в контексті підвищення енергетичної безпеки України. Івано-Франківськ : ІФНТУНГ. 2017. 274 с. 9. Поручник А.М., Кулаковський К.О. Енергетична безпека та диверсифікація енергоресурсів. Економіка та держава. 2017. № 8. С. 18-21. 10. Латишева О.В. Екологічні інвестиції: сучасний стан та перспективи їх впровадження в Україні для забезпечення сталого розвитку держави. Економічний вісник Донбасу. 2018. № 1 (51). С. 59-66. 11. Новікова О.Ф., Логачова Л.М. Формування умов гідної праці при подоланні виробничих небезпек у промисловості України. Економічний вісник Донбасу. 2018. № 1 (51). С. 97-109. 12. Музиченко М.В. Місце і роль диверсифікації постачання енергоносіїв у системі забезпечення енергетичної безпеки ЄС. Причорноморські економічні студії. 2017. Випуск 21. С. 15-18. 13. Опімах Р.Є. Диверсифікація енергопостачання в програмних підходах різних країн світу та її вплив на інтегральний показник енергетичної безпеки України. Актуальні проблеми міжнародних відносин. 2012. Випуск 108 (Частина I). С. 122-132. 14. Степанова А. Диверсифікація енергетичної залежності України. Вісник Київського національного університету імені Тараса Шевченка. Економіка. 2015. № 7(172). С. 69-73. 15. Аналіз зарубіжної практики 
впровадження автоматизованих систем управління технологічними процесами в електроенергетиці, 2014. Київ: ВП НТЦЕ ДП «НЕК «Укренерго». URL: https: //ua.energy/wp-content/uploads/2018/01/2.-SMART-GR ID.pdf. 16. Савчук С. Потужному ринку електротранспорту в Україні бути. Урядовий портал. 2017. URL: https:/www.kmu.gov.ua/ua/news/249919582. 17. Сущенко О., Гичка О. Цифрова революція для побудови “реальної" зеленої економіки. 2018. URL: http://prismua. org/. 18. Пушак Я.Я. Сучасні тенденції розвитку мережевої економіки на підприємствах в умовах глобальних викликів. Глобальні та начіональні проблеми економіки. 2017. № 18. С. 608-612. 19. Пушак Я.Я. Ефективність впровадження електронної системи як одного з інструментів мережевої економіки. Економіка і сусnільство. 2017. № 11. С. 625-629.

\section{References}

1. Trots I.V. (2012). Zabezpechennia ekonomichnoi bezpeky na pidpryiemstvi $\mathrm{z}$ metoiu poperedzhennia bankrutstva [Trotz IV Ensuring economic security at the enterprise in order to prevent bankruptcy]. Visnyk ZhDTU ZhSTU Bulletin, 1, pp. 223-227 [in Ukrainian].

2. Stohnii B.S., Kyrylenko O.V., Prakhovnyk A.V., Denysiuk S.P. (2012). Evoliutsiia intelektualnykh elektrychnykh merezh ta yikhni perspektyvy v Ukraini [The evolution of smart grids and their prospects in Ukraine]. Tekhnichna elektrodynamika - Technical electrodynamics, 5, pp. 52-67 [in Ukrainian].

3. Dudnikov S. M. (2014). Deiaki aspekty proektuvannia kombinovanykh systemy enerhopostachannia $\mathrm{z}$ ponovliuvalnymy dzherelamy $\mathrm{z}$ vrakhuvanniam kontseptsii Smart Grid [Some Aspects of Designing Combined Renewable Energy Supply Systems Considering Smart Grid Concept.]. Komunalne hospodarstvo mist-Utilities of cities, Issue 118 (1), pp. 67-70 [in Ukrainian].

4. Moroz O.M., Cheremisin M.M., Savchenko O.A., Popadchenko S.A., Diubko S.V. (2017). Vykorystannia tekhnolohii Smart Grid dlia pidvyshchennia efektyvnosti elektropostachannia spozhyvachiv [Use of Smart Grid technologies to improve the efficiency of electricity supply to consumers]. Enerhetyka: ekonomika, tekhnolohii, ekolohiia - Energy: Economics, Technologies, Ecology, 3 [in Ukrainian].

5. Prakhovnyk A.V. (2010). Vid upravlinnia elektrospozhyvanniam do enerhetyky staloho rozvytku [From power management to sustainable development]. Visnyk NTTU KPI». Seriia «Hirnytstvo» - NTTU KPI Bulletin. Mining series, Issue 19, pp. 110-121 [in Ukrainian].

6. Chernyshova M.I., Tulchynska S.O. (2016). Vprovadzhennia proektu "rozumni merezhi" v konteksti rozvytku palyvno-enerhetychnoho kompleksu Ukrainy [Implementation of the "smart grids" project in the context of the development of Ukraine's fuel and energy complex]. Efektyvna ekonomika - Efficient economy, 11. Retrieved from http://www.economy.nayka.com.ua/?op=1\&z=5272 [in Ukrainian].

7. Dzoba O.H. (2016). Pro deiaki aspekty otsiniuvannia enerhetychnoi bezpeky $\mathrm{z}$ urakhuvanniam ryzykiv subiektiv palyvno-enerhetychnoho kompleksu [On some aspects of energy security assessment taking into account the risks of the subjects of the fuel and energy complex]. Naukovyi visnyk Ivano-Frankivskoho natsionalnoho tekhnichnoho universytetu nafty $i$ hazu. Seriia «Ekonomika ta upravlinnia v naftovii $i$ hazovii promyslovosti», 1 (13), pp. 37-41 [in Ukrainian].

8. Dzoba O.H., Simkiv L.Ye., Kafka S.M. (2017). Ekonomiko-upravlinski aspekty transformatsii ta innovatsiinoho rozvytku sotsialno-ekonomichnykh system $\mathrm{v}$ konteksti pidvyshchennia enerhetychnoi bezpeky Ukrainy [Economic-managerial aspects of transformation and innovative development of socio-economic systems in the context of improving energy security of Ukraine]. IvanoFrankivsk, IFNTUNH [in Ukrainian].

9. Poruchnyk A.M., Kulakovskyi K.O. (2017). Enerhetychna bezpeka ta dyversyfikatsiia enerhoresursiv [Energy security and diversification of energy resources]. Ekonomika ta derzhava - Economy and state, 8, pp. 18-21 [in Ukrainian].

10. Latysheva O.V. (2018). Ekolohichni investytsii: suchasnyi stan ta perspektyvy yikh vprovadzhennia $\mathrm{v}$ Ukraini dlia zabezpechennia staloho rozvytku derzhavy [Environmental investments: current state and prospects of their implementation in Ukraine for sustainable development of the country]. Ekonomichnyi visnyk Donbasu Economic Herald of the Donbas, 1 (51), pp. 59-66 [in Ukrainian].

11. Novikova O.F., Lohachova L.M. (2018). Formuvannia umov hidnoi pratsi pry podolanni vyrobnychykh nebezpek u promyslovosti Ukrainy [Formation of decent work conditions for overcoming industrial hazards in the Ukrainian industry]. Ekonomichnyi visnyk Donbasu - Economic Herald of the Donbas, 1 (51), pp. 97-109 [in Ukrainian].

12. Muzychenko M.V. (2017). Mistse i rol dyversyfikatsii postachannia enerhonosiiv u systemi zabezpechennia enerhetychnoi bezpeky YeS [The place and role of energy supply diversification in the EU's energy security system]. Prychornomorski ekonomichni studii-Black Sea Economic Studies, Issue 21, pp. 15-18 [in Ukrainian].

13. Opimakh R.Ye. (2012). Dyversyfikatsiia enerhopostachannia $\mathrm{v}$ prohramnykh pidkhodakh riznykh krain svitu ta yii vplyv na intehralnyi pokaznyk enerhetychnoi bezpeky Ukrainy [Diversification of energy supply in programmatic approaches of different countries of the world and its influence on the integral index of energy security of Ukraine]. Aktualni problemy mizhnarodnykh vidnosyn Topical problems of international relations, Issue 108 (Part I), pp. 122-132 [in Ukrainian].

14. Stepanova A. (2015). Dyversyfikatsiia enerhetychnoi zalezhnosti Ukrainy [Diversification of Ukraine's energy dependence]. Visnyk Kyivskoho natsionalnoho universytetu imeni Tarasa Shevchenka. Ekonomika - Bulletin of Taras Shevchenko National University of Kyiv. Economy, 7(172), pp. 69-73 [in Ukrainian].

15. Analiz zarubizhnoi praktyky vprovadzhennia avtomatyzovanykh system upravlinnia tekhnolohichnymy protsesamy $\mathrm{v}$ elektroenerhetytsi [Analysis of the foreign practice of implementation of automated process control systems in the electric power industry]. (2014). Kyiv, VP NTTsE DP «NEK «Ukrenerho». Retrieved from https: //ua.energy/wp-content/uploads/2018/01/2.-SMARTGRID.pdf [in Ukrainian].

16. Savchuk S. Potuzhnomu rynku elektrotransportu v Ukraini buty [Powerful market of electric transport in Ukraine to be]. (2017). Uriadovyi portal - Government 
portal. Retrieved from https://www.kmu.gov.ua/ua/ news/ 249919582 [in Ukrainian].

17. Sushchenko O., Hychka O. (2018). Tsyfrova revoliutsiia dlia pobudovy "realnoi" zelenoi ekonomiky [The digital revolution for building a "real" green economy]. Retrieved from http://prismua.org/ [in Ukrainian].

18. Pushak Ya.Ya. (2017). Suchasni tendentsii rozvytku merezhevoi ekonomiky na pidpryiemstvakh $\mathrm{v}$ umovakh hlobalnykh vyklykiv [Modern tendencies of development of the network economy at the enterprises in the conditions of global challenges]. Hlobalni ta natsionalni problemy ekonomiky - Global and national problems of economy, 18, pp. 608-612 [in Ukrainian].

19. Pushak Ya.Ya. (2017).Efektyvnist vprovadzhennia elektronnoi systemy yak odnoho $\mathrm{z}$ instrumentiv merezhevoi ekonomiky [Efficiency of introduction of electronic system as one of tools of network economy]. Ekonomika $i$ suspilstvo - Economy and society, 11, pp. 625-629 [in Ukrainian].

Завербний А. С., Пушак Г. І. Проблеми та перспективи впровадження структур інтелектуальних електроенергетичних мереж в Україні задля підвищення рівня енергетичної безпеки

У статті сформульовано та обгрунтовано перспективи впровадження структур інтелектуальних електроенергетичних мереж в Україні задля підвищення рівня енергетичної безпеки. Виявлено проблеми впровадження цих мереж в Україні для підвищення рівня іiі енергетичної безпеки. Вивчено сутність енергетичної безпеки країни, фактори які впливають на ії рівень. Визначено сутність інноваційної енергетичної системи, що грунтується на концепції «Smart Grid». Наведено переваги даної концепції над діючою в Україні на сьогодні. В статті наведено новітне позиціонування економічної політики України у сфері енергетики. Побудовано систему взаємозв'язку стейкхолдерів, вимог та ефектів в процесі реалізації концепції «Smart Grid» в енергетиці України. Розглянуто етапи ії формування. Проаналізовано загальну функціонально-технологічну ідеологію концепцію системи «Smart Grid» та можливості застосування в Україні. Визначено необхідність для енергетичного сектору України переймання досвіду Європейського Союзу, США, Китаю, інших країн, в яких на рівні держави прийняті, успішно реалізуються національні концепції розвитку, фінансування «інтелектуальних» мереж в електроенергетиці, інших галузях економіки, що стали основою для формування національних енергетичних політик, програм, енергетичних стратегій розвитку тощо

Ключові слова: енергетична безпека, інтелектуальні електроенергетичні мережі, електроенергетика.

Zaverbnyj A., Pushak H. Problems and Prospects of Implementation the Structures of the Intellectual Electricity Networks in Ukraine to Increase the Level of Energy Security

The article formulates and substantiates the prospects for introducing the structures of intelligent electric power networks in Ukraine to increase the level of energy security. The problems of introducing these networks in
Ukraine to improve its energy security are identified. The essence of the country's energy security, factors affecting its level are studied. The essence of the innovative energy system based on the concept of "Smart Grid" is determined. The advantages of this concept over the current in Ukraine today are given. The article presents the latest positioning of Ukraine's economic policy in the energy sector. A system of interconnection of stakeholders, requirements and effects in the process of the feasibility of the Smart Grid concept in the energy sector of Ukraine was built. The stages of its formation are considered. The general functional and technological ideology of the concept of the Smart Grid system and the possibility of application in Ukraine are analyzed. The need for the energy sector of Ukraine to borrow the experience of the European Union, the USA, China, and other countries in which they are accepted at the state level is successfully implemented; national concepts of development, financing of "smart" networks in the electric power industry and other sectors of the economy are successfully implemented; they have become the basis for the formation of national energy policies, programs, energy development strategies, etc.

Keywords: energy security, intelligent electric power networks, electric power industry.

Завербный А. С., Пушак Г. И. Проблемы и перспективы внедрения структур интеллектуальных электроэнергетических сетей в Украине для повышения уровня энергетической безопасности

В статье сформулированы и обоснованы перспективы внедрения структур интеллектуальных электроэнергетических сетей в Украине для повышения уровня энергетической безопасности. Выявлены проблемы внедрения этих сетей в Украине для повышения уровня ее энергетической безопасности. Изучены сущность энергетической безопасности страны, факторы, влияющие на ее уровень. Определена сущность инновационной энергетической системы, основанной на концепции «Smart Grid». Приведены преимущества данной концепции над действующей в Украине на сегодня. В статье приведено новейшее позиционирования экономической политики Украины в сфере энергетики. Построена система взаимосвязи стейкхолдеров, требований и эффектов в процессе реализации концепции «Smart Grid» в энергетике Украины. Рассмотрены этапы еe формирования. Проанализированы общая функционально-технологическая идеология концепции системы «Smart Grid» и возможности применения в Украине. Определена необходимость для энергетического сектора Украины заимствования опыта Европейского Союза, США, Китая, других стран, в которых на уровне государства приняты, успешно реализуются национальные концепции развития, финансирования «интеллектуальных» сетей в электроэнергетике, других отраслях экономики, стали основой для формирования национальных энергетических политик, программ, энергетических стратегий развития и т.д.

Ключевые слова: энергетическая безопасность, интеллектуальные электроэнергетические сети, электроэнергетика.

Received by the editors: 07.11.2019 and final form 19.12.2019 